\title{
Clashing Interests in the Eastern Mediterranean: What About Turkey?
}

\author{
MEHMET EFE BIRESSELIOĞLU*
}

\begin{abstract}
The Eastern Mediterranean region has recently emerged as one of the pivotal foci of international affairs due to its considerable natural gas reserves. The region has become a point of intersection for surrounding countries and external actors, as well as major energy market players. The main challenge associated with Eastern Mediterranean natural gas is the position of the reserves in the Mediterranean Sea and the resulting ownership problem among its littoral states, while the de facto division of, and disputes over, the island of Cyprus is closely connected to the issue. Hence, the debates involve two key questions: (1) which countries have ownership rights, and (2) which countries will be the natural gas transit countries. This article examines the standpoints of Turkey and the other actors involved in the game in the Eastern Mediterranean. The positions are presented with a focus on how different actors interpret current developments, perceive threats, and formulate their reactions.
\end{abstract}

\section{Introduction}

T oday's understanding of the concept of energy security relies on a more structured framework, as compared to that of previous decades. Following its emergence in the aftermath of the 1970s oil crises, the understanding of energy security was mainly centered around the concerns about security of supply, more specifically the impact of price on the. ${ }^{1}$ Like many other commodities in the world, there was greater interest in energy security when energy prices were high, and less when they were low, such as the period from the late 1980s to the late 1990s. Nevertheless, the limited availability of fossil fuel reserves, especially oil, and later, natural gas, and their concentration in areas such as the Middle East, Africa, and Russia; has triggered a high level of dependency on these regions for both developed and developing countries lacking sufficient reserves, thus jeopardizing their security of supply. The geopolitical changes in the world after the end of the Cold War broadened the concept of energy security, such that explaining it only in terms of the security of supply is no longer adequate.

Increasing uncertainty in energy-producing countries and regions and the growing risk of terrorism brought the issue of energy infrastructure safety

* Izmir University of Economics, Turkey

Insight Turkey

Vol. 21 / No. 4 / 2019, pp. 115-134 
With its considerable natural gas reserves, the Eastern Mediterranean region has recently emerged as one of the pivotal foci of international affairs with the convergence of political, economic, and geostrategic dynamics into the matrix. As demonstrated by previous research evaluating the nature of terrorist attacks on energy infrastructure, the world has experienced almost 5,000 such terrorist attacks in more than 90 countries since the 1970s. ${ }^{2}$

A further concern that deserves attention is the impact of emerging economies such as China, India, Brazil, and Russia, and fast-growing economies such as Turkey, Indonesia, Mexico, and South Korea on global demand. Like developed economies, these countries are highly dependent on energy supply, particularly fossil fuels. In comparison to low-income economies, where more than 50 percent of total energy is consumed by households, the emerging and fast-growing economies have higher shares of industrial consumption, translating into massive energy demand. ${ }^{3}$ Hence, the increasing demand arising from such countries also poses a threat to contemporary global energy security, highlighting the role of energy demand against security of supply.

Another significant component of energy security emanates from geopolitical rivalries and risks. As argued by the present author, ${ }^{4}$ global geopolitics is rapidly shifting due to economic and political crises and conflicts at the national, regional, and global levels, mainly arising from power politics. However, one can no longer limit the dynamics of power politics to the classical understanding of realpolitik, which is the result of the anarchical international system. Today, it is no longer plausible to argue that power politics involves only, or even mainly, states. It is important to consider other stakeholders, for instance, energy corporations such as Chevron, BP, Gazprom, Eni, and Shell; international organizations such as the International Energy Agency (IEA), the Organization of Petroleum Exporting Countries (OPEC), and the International Renewable Energy Agency (IRENA); and international regimes and institutions that regulate energy markets and trade and determine environmental standards, such as the United Nations Framework Convention on Climate Change (UNFCCC), the World Trade Organization (WTO), and the Energy Charter Treaty. The involvement of non-state stakeholders makes power politics more complex and changeable, creating greater geopolitical risks and involving many diverse interests. ${ }^{5}$

Nor should the contemporary approach to energy security ignore environmental concerns, especially considering the climate change and global warming now being experienced globally. ${ }^{6}$ As argued by many, the environmental 
challenges that we are experiencing today are the result of record levels of fossil fuel consumption. Despite all efforts to reduce it, the share of fossil fuels in global energy consumption in 2018 was 85 percent. ${ }^{7}$ Efforts to decrease the share of fossil fuels, stemming from a growing awareness of environmental issues, began in the 1990s with the signing of the Kyoto Protocol, led by European countries. Although frequently criticized, the Kyoto Protocol was an important first step, leading eventually to the Paris Agreement of today. The main target of these agreements is simply to decrease the current level of carbon emissions, caused mainly by fossil fuel consumption. ${ }^{8}$

As a result, previous definitions of the energy security concept, such as the IEA's, which consider only availability and price, are no longer sufficient to address contemporary challenges. ${ }^{9}$ Conversely, the European Commission's conceptualization, encompassing all political, economic, security, environmental, and socio-demographic factors, concisely addresses all challenges: "[the] strategy for energy supply security must be geared to ensuring, for the well-being of its citizens and the proper functioning of the economy, the uninterrupted physical availability of energy products on the market, at a price which is affordable for all consumers, while respecting environmental concerns and looking towards sustainable development." ${ }^{\prime 0}$

\section{Growing Global Interest in Natural Gas: The Energy Security Perspective}

As mentioned in the preceding section, high dependency levels and the increasing global pressure related to environmental concerns have led countries to prioritize increasing alternative energy sources in their energy mix to replace oil and coal. At this point, natural gas emerged as a strong alternative, as an efficient and reliable source less harmful to the environment. ${ }^{11}$ Low natural gas prices, especially in the 1990s and early 2000s, allowed its wider spread among consumer countries. Today, natural gas accounts for 24 percent of global energy consumption, the third highest share following oil and coal. ${ }^{12}$ Global consumption has almost doubled in three decades from $1,948 \mathrm{bcm}$ in 1990 to $3,848 \mathrm{bcm}$ in $2018 .{ }^{13}$ Initially, the main demand originated from OECD countries such as the United States (U.S.), Germany, Turkey, Italy, and South Korea; however, today, due to issues such as air pollution, high levels of economic growth, and increasing energy needs, many non-OECD countries are also consuming higher levels. For instance, China's natural gas consumption has increased almost six-fold in only 13 years, from $47 \mathrm{bcm}$ in 2005 to $283 \mathrm{bcm}$ in 2018. Today, the U.S. is the leading producer, accounting for 21.5 percent of global production, followed by Russia, Iran, and Qatar accounting for 17 percent, 6 percent, and 4.5 percent, respectively. In terms of exports, Russia is the main exporter of piped gas and Qatar is the main exporter of liquefied natural 
The main challenge associated with the Eastern Mediterranean natural gas is the position of the reserves in the Mediterranean Sea and the consequent ownership problem among its littoral states gas (LNG), accounting for $223 \mathrm{bcm}$ and $105 \mathrm{bcm}$, respectively. ${ }^{14}$

Natural gas is rapidly increasing in terms of demand and production, but its transportation is more difficult compared to other fossil fuels. Currently, there are only two feasible transportation methods: via pipelines or by transporting LNG by vessels. ${ }^{15}$ Both require significant

infrastructure or equipment investments, which few countries and energy companies can afford. There are also several challenges to natural gas supply, such as the increase in global demand, unstable prices, lack of diversification, dependence on a single supplier, as well as political, legal, and economic problems in both producing regions and transit countries. ${ }^{16}$ As a result, there is intense rivalry over the world's tapped and untapped natural gas resources.

With its considerable natural gas reserves, the Eastern Mediterranean region has recently emerged as one of the pivotal foci of international affairs with the convergence of political, economic, and geostrategic dynamics. The region has become the point of intersection for regional actors such as Turkey, Greece, Israel, and Egypt; major energy market players such as BP, ENI, Total, and Exxon; and countries in need of energy supply, such as EU member countries and Turkey.

The main challenge associated with the Eastern Mediterranean natural gas is the position of the reserves in the Mediterranean Sea and the consequent ownership problem among its littoral states. This problem becomes even more critical when one considers the de facto division of, and dispute over, the island of Cyprus. At this point, there are two key issues: (1) which countries have ownership rights, and (2) which countries will be the natural gas transit countries. The countries that are able to control the production and exports are most likely to wield the greatest influence, both in the region and globally.

\section{Power Politics in the Eastern Mediterranean}

Although the littoral states in the Eastern Mediterranean seek to achieve their targets through the pursuit of their national interests, which include the ownership, exploration, exploitation, and transportation of the resources, they have also created a common institutionalized formation, establishing Eastern Mediterranean Gas Forum (EMGF) as a first step. This institutionalized framework is planned to be centered around geopolitical interests, joint economic 


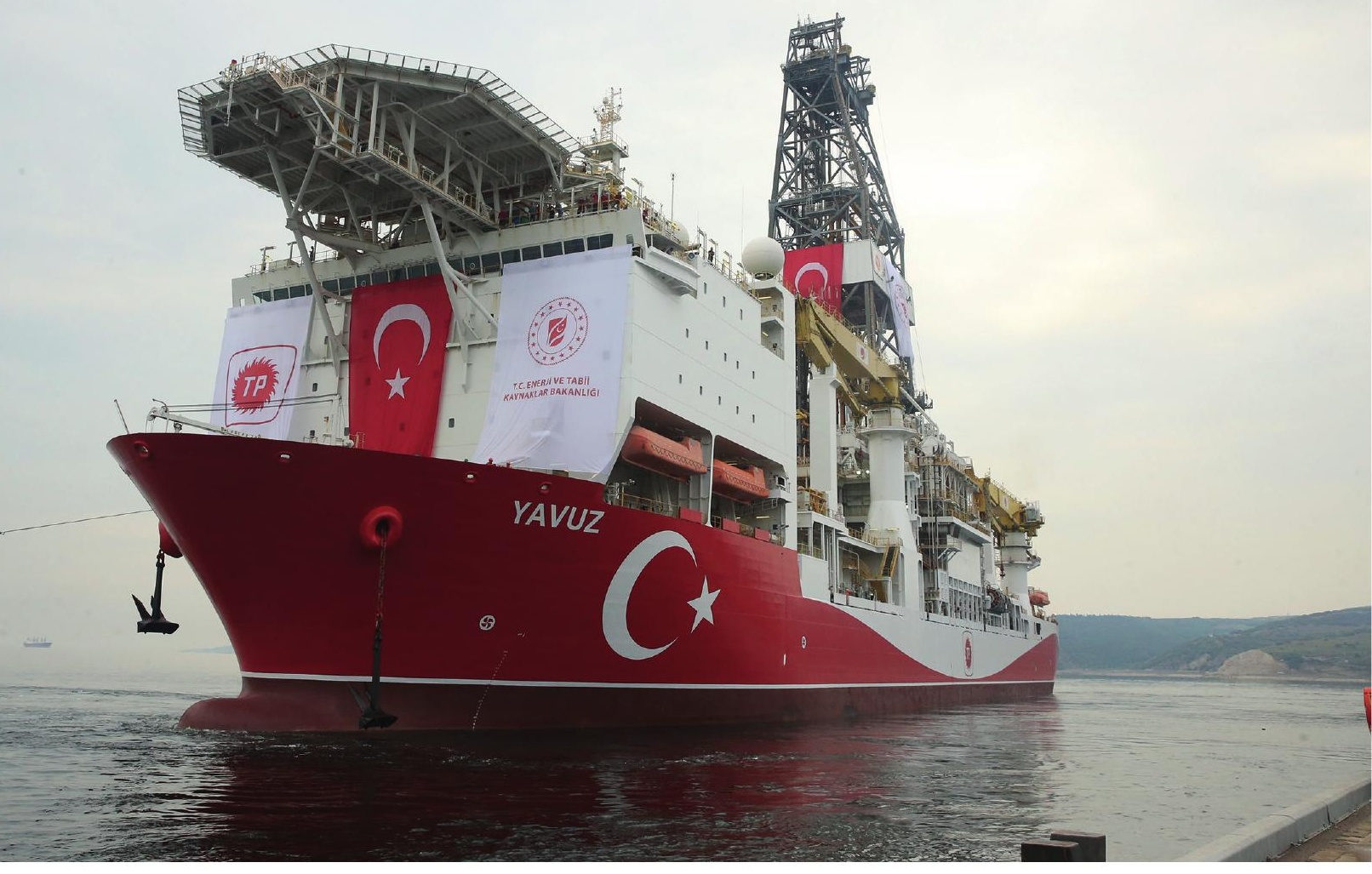

and trade benefits, and the energy security of the parties involved - Egypt, Greece, the Greek Cypriot Administration (GCA), Israel, Jordan, and Italy at the state level, excluding Turkey and the the Turkish Republic of Northern Cyprus (TRNC), and including the support of the EU and U.S. ${ }^{17}$ The next step is to elevate the EMGF to an international organization and to extend it through the formation of partnerships with the energy industry.

Among developments that may have contributed the establishment of the EMGF are (1) the gas export agreement between Egypt and Israel, (2) the trilateral meeting between the GCA, Greece, and Egypt in Crete, (3) the increasing Turkish drilling activities in the region, (4) the strengthening of the strategic relationship between Israel and the U.S., (5) the EU's support to its member states of Greece and the GCA, and (6) the involvement of American and Italian energy companies in drilling activities in the region.

Several developments led to the exclusion of Turkey, Lebanon, and Syria from the matrix. The first involves the increasing trilateral cooperation between the GCA, Greece, and Israel following the Greek economic crisis, and the ongoing challenges between Turkey and Israel. The second significant factor has to do with the ongoing disputes between Turkey and the GCA, and Israel and Lebanon regarding natural gas fields. The third is the current Syrian conflict. ${ }^{18}$

Excluding Turkey from the formation of the forum shifted the tendencies of the previously cooperative states in the region toward undermining or taking

Turkey's second drilling ship 'Yavuz' heads towards the Mediterranean Sea in Kocaeli's Dilovası district before beginning its operations on June 20, 2019.

TAHIR TURAN EROĞLU AA Photo 
a position against Turkey's interests. For instance, the joint talks between Turkey and Israel to construct an economically viable pipeline through Turkey no longer continue. Instead, the EastMed gas pipeline project aiming to export gas to European countries via Crete is under discussion. Compared to the former, the latter is not economically or technically viable. However, it is supported by Israel and the GCA due their clashing interests with Turkey and the TRNC concerning the de facto partition of the island and Israel's long-standing ties with the GCA. ${ }^{19}$ The institutional mechanism established through the EMGF acts as a facilitator in this direction, enhancing communication channels between Israel and the GCA, as well as other stake-holding producer and consumer states.

The tendency of Egypt, Greece, the GCA, Israel, Jordan, and Italy to bypass Turkey in the Eastern Mediterranean through East-Med can be explained by the Institutionalist Theory in International Relations on the basis of the transformational model suggested by Dessler. ${ }^{20}$ This model argues that international norms shape the international system. Firstly, the existing set of rules is set forth in order to create a common basis and define the standpoints of the parties involved. This framework is then utilized to support prospective actions. Finally, as a consequence of the actions taken, either the existing rules are altered or new rules are developed.

Within this framework, Turkey's initial inclusion in the regional energy scenario as a location for possible natural gas export routes and pipeline projects, and its subsequent exclusion can be explained by the transformational model of Institutionalism. Furthermore, the realpolitik approach also identifies the littoral states' orientation to pursue their national interests within international structures. In this sense, the realpolitik approach explains how the GCA garners support from the EU and tries to justify its claims over the entire island of Cyprus.

Turkey's position demonstrates the other side of the coin. Its approach consists of working through its bilateral relations with the states in the region. The de facto partition of Cyprus and the unilateral non-recognition of the TRNC are the key issues behind the disputes on Exclusive Economic Zone (EEZ), ownership problems and the exclusion of Turkey and the TRNC from the institutional framework that has been set by the EMGF parties, the U.S., and the EU. Therefore, Turkey's approach appears to follow another ontological model; i.e., it is more positional then transformational. As Dessler argues, ${ }^{21}$ the positional model involves three sequential phases: (1) action, (2) interaction, and (3) results. In the case of Turkey, this involves a reaction and its consequential results, such as the ongoing explorations.

This study traces the phases of the process induced by the positional model implemented by both Turkey and the TRNC, with consideration of the trans- 
formational model that followed by the opposing camp. This will be done through an examination of the statements and counter-statements from both sides. Therefore, this study identifies the standpoints of Turkey and other actors involved in the game in the Eastern Mediterranean, considering their rights over the ownership of the reserves and their exports. Turkey's position is presented within a conceptual framework, utilizing statements of the two camps about how the parties interpret the current developments pertaining to Turkey in the region, and how they perceive threats and reciprocal reactions concerning the existing strategic moves. Discourse

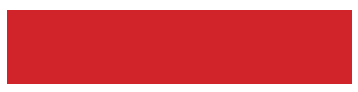

The gas discoveries failed to create the hoped-for regional cooperation; instead, tensions in the region further increased analysis is applied to the statements from both camps, which were compiled from news agencies, press statements and interviews with experts and academics. The analysis cites quotations from public statements of government officials and diplomats to compare the different perceptions and conceptualizations of the different parties, including Turkish diplomats and experts, and representatives from other involved actors.

\section{Energy Profiles of Eastern Mediterranean Countries}

The countries in the Eastern Mediterranean are undergoing a series of changes in their energy landscapes. While the population of this region and its economic development are expected to further increase its energy demand in the following decades, the lack of sufficient energy resources poses a threat for the future. ${ }^{22}$ The discovery of large hydrocarbon resources in the offshore Eastern Mediterranean has a significant potential to alter the situation and remove this threat. Hydrocarbon resource exploration and drilling activities mean that the region is likely to become an energy hub in the next decades. ${ }^{23}$

The development of the hydrocarbon sector in the Eastern Mediterranean dates back 80 years, but the currently limited global natural gas reserves have only recently begun to attract the attention of state actors to this region, which is rich in hydrocarbon resources, particularly in natural gas reserves. ${ }^{24}$ The Eastern Mediterranean has become a focus of interest with respect to access to energy reserves and control of pipelines in the region. Since 2009, a series of natural gas discoveries in the region began an era of exploration and drilling led by BP, ENI, Exxon, and Total.

Discoveries of large natural gas reserves in the region started in Israel in 2005, followed by discoveries around Cyprus in 2011, and finally in Egypt in 2015. This decade significantly altered the regional energy landscape of the littoral 



\section{The divided status of Cyprus is the main cause of controversy in the natural gas exploration activities around the island}

The discovery of rich natural gas reserves in the Levant basin encouraged exploration and drilling activities by other countries. The GCA extended exploration activities in 2011 to the offshore territory, where approximately 180 bcm of gas was discovered. ${ }^{30}$ In a unilateral decision by the GCA, the exploration and drilling fields near the island of Cyprus were divided into 13 blocks, in which drilling activity was undertaken by companies such as Eni, Total, EXXON Mobil, Shell, Noble Energy, Qatar Petroleum, Delek Group, and Kogas. ${ }^{31}$ The two most prominent gas discoveries were in Block 12 of the Aphrodite field and Aphrodite-2, which is located on the Israeli side of the maritime boundary with the island of Cyprus.

Following the exploration activities in Israel and the GCA, the large gas reserves discovered in Egypt in 2015 enabled Egypt to become a natural gas exporter. Egypt had experienced a serious decline in natural gas production, from a peak of 5.8 bcf per day in 2009 to 3.9 bcf per day in $2016,{ }^{32}$ but a series of offshore natural gas exploration activities off the Egyptian coast changed the country's energy outlook. The West Nile Delta, Nooros, Atoll, and Zohr fields were the major areas for exploration activities. The Zhor gas field was the most prominent discovery in Egypt at this time, holding approximately $850 \mathrm{bcm}$ of gas, making it the largest natural gas reserve in the Mediterranean. It provided an opportunity for Egypt to free itself from dependence on LNG imports, and increase its export volume. ${ }^{33}$ Thus, Egypt's progress in gas exploration activities overtook those of Israel and the GCA. Moreover, the recent discovery in the Nile Delta area -with an estimated production of 20 million cubic feet per day- strengthened Egypt's position toward as a net gas exporter. $^{34}$

However, the gas discoveries failed to create the hoped-for regional cooperation; instead, tensions in the region further increased. The main factors causing the rise in tensions are geopolitical conflicts, the economic and commercial interests of the littoral states, increasing energy demand, the shift in supply and demand balance, the threat of terrorism, and political problems. ${ }^{35}$ In short, there are four classes of disputes in the region: territorial, geopolitical, economic, and social.

Among these disputes and tensions, those that involve Turkey includes continental shelf, Turkey's attempt to dispatch a second drilling ship to the TRNC, the potential sanctions on Turkey planned by the EU due to its activities in the region, Turkey's purchase of the S-400 air and missile defense system from 
Russia, Turkey's intervention to block the Italian company Eni in the Mediterranean, the creation of the Eastern Mediterranean Gas Forum, and the U.S. Committee delegated to report on Turkey's drilling activities in the Eastern Mediterranean.

\section{Turkey's Position in the Eastern Mediterranean}

Although Turkey does not possess significant oil and gas resources, ${ }^{36}$ it has an increasing strategic importance as a major energy transit country, with pipeline projects such as the Baku-Tbilisi-Ceyhan Pipeline, the Baku-Tbilisi-Erzurum Pipeline, the Trans Anatolian Pipeline (TANAP), Blue Stream, the Tabriz-Erzurum Pipeline, the Kirkuk-Yumurtalık Pipeline, the Turkey-Greece Interconnector, and the incomplete Turkish Stream. ${ }^{37}$ Meanwhile, strong opposition from involved and interested parties in the region hinders Turkey's efforts in gas exploration and drilling.

The divided status of Cyprus is the main cause of controversy in the natural gas exploration activities around the island. While the TRNC, which was established in 1983, has been recognized by Turkey alone, the international recognition of the GCA enables it to conduct unilateral drilling activities, violating Turkey's continental shelf in Blocks 1, 4, 5, 6, and 7. Thus, the overlapping interests of regional neighbors and organizations create jurisdictional concerns for offshore oil and gas drilling. The EEZ proposed by Greece and the GCA and the continental shelf argument proposed by Turkey are not aligned. This stems from the fact that Turkey is not a signatory of the United Nations Convention on the Law of the Seas (UNCLOS), whereas Greece and the GCA are. ${ }^{38}$ Turkey bases its position primarily on the principles of agreement, equitable solution, and provisional arrangements as referenced in articles 74 and 83 of the UNCLOS, pertaining to EEZ and Continental Shelf respectively. Turkey also claims that "the delimitation of [the] continental shelf in a semi-enclosed sea like the Mediterranean should be effected by agreement respecting [the] rights and interests of the countries concerned under international law, both customary and case-law," and "... of the legal opinion that the Island of Cyprus in the west and the Greek Islands in the area including Castellorizo cannot generate full EEZ/CS under international law as they distort the equitable delimitation." 39

Some politicians as well as the mainstream press in the West overwhelmingly portray Turkey's drilling and exploration activities as a violation of the GCA's EEZ. This perspective reinforces the efforts to exclude Turkey through restrictions and to halt its activities by threats of sanctions. Turkish officials and experts, on the other hand, claim that the attempts to restrict Turkey's activities in the Eastern Mediterranean are unjustified, and are aimed at prevent- 
ing Turkish Cypriots from utilizing the island's natural resources. Turkey also asserts that its activities in the region are aimed to "exercise its sovereign rights." Mevlüt Çavuşoğlu, the Minister of Foreign Affairs, has opposed the claims of the Greek Cypriots: "Turkey does not recognize the unilateral and illegitimate exclusive economic zone claims of the Greek Cypriots." ${ }^{40}$ Similarly, Fatih Dönmez, the Minister of Energy and Natural Resources, has stressed that Turkey would maintain its activities and operations on its continental shelf: "Turkey will continue its operations in areas where the TRNC has licensed the Turkish Petroleum Corporation." ${ }^{41}$

Accordingly, Turkey's first drilling vessel Fatih started to conduct natural gas exploration activities on the Turkish continental shelf near the island of Cyprus, in the vicinity of Blocks 1 and 6. These activities have created disputes at the international level. The GCA unilaterally claims that the area is their EEZ and under their control, implying that the island's entire coastline belongs to the GCA. Contrary to these claims, however, the supposed EEZ is not in fact among the areas unilaterally licensed by Nicosia for gas exploration and drilling activities. Following this logic, Turkey launched a second ship, Yavuz, to operate in the Eastern part of Cyprus. As the dispute grew, the U.S., as an international actor, became more involved. U.S. State Department Spokesperson Morgan Ortagus stated: “The U.S. remains deeply concerned by Turkey's repeated attempts to conduct drilling operations... This provocative step raises tensions in the region... We urge Turkish authorities to halt these operations... We continue to believe the island's oil and gas resources should be equitably shared between both communities. ${ }^{42}$

These developments caused Greece to call on the European Council to warn Turkey to restrict its activities. Alexis Tsipras, the then Greek Prime Minister, made the following declared: "[The] European Council should examine specific measures against those involved in these illegal activities... if Turkey insists on violating international law." ${ }^{43}$ French President Emmanuel Macron supported the sovereign prerogative of the GCA in offshore drilling for gas and regards Turkey's activities as illegal: “Turkey must stop its illegal activities in Cyprus' exclusive economic zone... The Greek Cypriots are the internationally recognized government of the island." ${ }^{44}$ Similarly, Jeremy Hunt, the former British Foreign Minister, argued that the right to income from the production of hydrocarbons belongs to the Greek Cypriots: "All parties must demonstrate prudence and restraint to Greek Cypriots on this issue." 45 


\section{Turkey's increasing energy demand and dependency on Russian gas mean that the search for alternatives to diversify its energy resources is inevitable}

Nevertheless, Turkey's attitude shows no signs of retreat from its decisive position. President Recep Tayyip Erdoğan pertinaciously defended Turkey's exploration activities in the Eastern Mediterranean with its two drilling ships, stating "Turkey does not have any intention to violate the rights of any parties to work in the region...

Turkey takes steps to defend the rights of Turkish Cypriots... The residents living on the island of Cyprus as a whole have a right to have a say on these areas." ${ }^{\prime 6}$ Energy Minister Dönmez stated: "Those trying to push Turkey out of [the] energy equation in [the] Eastern Mediterranean are aware that there is no realistic solution without Turkey." ${ }^{77}$ Similarly, Melih Han Bilgin, General Manager of Turkish Petroleum indicated: "We have no hesitation in carrying out our work in areas licensed to us by the Republic of Turkey... or in licensed zones transferred to our institution by the TRNC." 48 Mustafa Akinc1, the President of the TRNC, also expressed his opinions regarding the disputes on natural gas drilling activities around the island and the rights of the Turkish Cypriots. He underlined that both the TRNC and Turkey hoped to find a solution to the problems experienced on the island of Cyprus through bilateral negotiations, stating: "The TRNC will definitely continue to defend its rights in the Eastern Mediterranean together with the Republic of Turkey... The TRNC is actually ready to do whatever necessary to show its determination." ${ }^{49}$

The problems and tensions regarding the maritime boundaries in the Eastern Mediterranean require the establishment of a legal framework to regulate the exploration of hydrocarbon resources. However, the lack of a clear agreement in the delimitation of the EEZ prevents an understanding between regional actors. ${ }^{50}$ As a result, Cyprus has become a predicament for the two communities living on the island and for the state actors participating in gas exploration activities. For instance, when the drilling ship of the Italian company Eni was obstructed by Turkish warships near Cyprus, Nicos Anastasiades, President of the GCA, declared that Turkey had "violated international law by blocking the ship" and the GCA government would "take necessary steps" in response. ${ }^{51}$ On the other hand, the Turkish government stated that the ship was blocked because its area of operation was within Turkey's or the TRNC's zone of authority. Çavuşoğlu stated: "[The] Greek Cypriots are jeopardizing security and stability in the region with their claims." ${ }^{2}$ In the same direction, İbrahim Kalın, Presidential Spokesperson, criticized the attitude of the GCA: “Turkey strongly rejects the fait accompli policy of the GCA in [the] Eastern Mediterranean... Turkey will continue to advocate [for] the rights of Turkish Cypriots in the region." 53 
estinians' struggle for independence, which raised the tension between these two countries. Meanwhile, Israel's decision to export its surplus natural gas to Europe through the GCA has been perceived by Turkey as a strategic move to undermine Turkey. TRNC President Akıncı also responded to the projected bypass of Turkey, stating, "[The] EastMed pipeline is not a peaceful route... A more economic, rational and peaceful solution that will contribute to regional peace should be preferred... Otherwise, this attempt will only serve to the permanent division of Cyprus." ${ }^{5}$

\section{The Risk of Exclusion and Sanctions}

Turkey's drilling and exploration activities in the Eastern Mediterranean are perceived by regional actors and supranational organizations as illegal. The envisaged outcome is that these activities are bound to damage Turkey's relations with its neighbors, particularly with the EU. In this respect, the European Council supports Greece in the dispute over the demarcation of the continental shelf and the EEZ, and calls on Turkey to restrain its activities in the region. Donald Tusk, the former president of the European Council, argued that the European Council had the responsibility to support the GCA: "I expect the European Council to confirm its full solidarity with Cyprus... and its readiness to respond appropriately." ${ }^{56}$ Turkey is also threatened by other regional powers with prospective sanctions. Senior EU officials have been evaluating the possibilities regarding these sanctions: "One option was to end talks with Turkey over extending a customs union... Another option is suspending Turkey's status as an official candidate to become a member of the European Union." ${ }^{57}$

As a response, Turkish officials have announced that Turkey would not recognize the unilateral agreements violating Turkey's rights and sovereignty in the region. Energy Minister Dönmez, believing that any such agreements attempt to deny the rights of Turkey and Turkish Cypriots, stated, "Unilateral agreements made between [the] island of Cyprus and the regional countries had no legal validity." ${ }^{58}$ Similarly, Foreign Minister Çavuşoğlu indicated that it was impossible for Turkey to accept third parties taking the role of the international court in identifying maritime boundaries. ${ }^{59}$

Turkey risks the imposition of sanctions from other countries as well as international organizations, and, as noted above, has been excluded from the Eastern Mediterranean Gas Forum, which was established by the Energy Ministers of Israel, Italy, the Palestinian Authority, the GCA, Egypt, Jordan, and Greece in 2019 for regional cooperation. The fundamental aim of the Forum was to establish a regional market to satisfy the interests and objectives of the participating members, while reducing infrastructure costs and maintaining 
competitive prices. The Forum initially excluded Turkey, Syria, and Lebanon; but Syria and Lebanon were invited to join after the negotiations in April, leaving Turkey excluded.

Following all of these incidents, the Eastern Mediterranean Security and Partnership Act, which passed the Foreign Relations Committee of the U.S. Senate in 2019, required a U.S. committee to report on Turkey's drilling activities in the Eastern Mediterranean. Turkey was not mentioned by name; however, the Act provided for the reporting to the U.S. of any hindrance to the GCA's drilling within its EEZ and any "illegal activities" in the Eastern Mediterranean.

All of the efforts to restrict Turkey's position and ac-

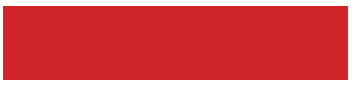

Turkey's engagement in the region is not only based on satisfying its energy demand, but also on exercising its own sovereign rights and advocating for those of the Turkish Cypriots tivities in Eastern Mediterranean create challenges in terms of Turkey's energy security. Turkey's increasing energy demand and dependency on Russian gas mean that the search for alternatives to diversify its energy resources is inevitable. ${ }^{60}$ However, this search is hampered by the restrictions caused by political conflicts hindering Turkey's exploration and drilling activities in the resource-rich Eastern Mediterranean region, throwing doubt on its potential role to act as an energy hub for European countries through pipeline projects.

\section{Conclusion}

Historically the Eastern Mediterranean region, particularly the island of Cyprus, has been a conflict-prone region of strategic importance with respect to the surrounding and external states' interests. The strategic importance of this region increased significantly as a result of the recent discoveries of large natural gas reserves. However, natural gas exploration and drilling activities have failed to generate regional cooperation between the littoral states; rather, these activities have escalated the rivalry between regional actors, increasing the likelihood of serious conflicts.

Although it is one of the prominent resource discoveries in the Eastern Mediterranean, natural gas is not the only driving factor behind regional competition. The competition is also intensified by the region's strategic geographical location and the ambitions of energy producers and consumer countries to increase their influence there. To this end, the involved and interested parties have created alignments designed to exclude Turkey. 
An equal allocation of the natural resources and the protecting all parties' sovereign rights without discrimination will facilitate the diplomatic resolution of the outstanding regional disputes
However, Turkey refuses to abandon the Eastern Mediterranean because of its legal rights over the island of Cyprus. As mentioned in the previous sections, Turkey has undertaken various initiatives to achieve its objectives in the Eastern Mediterranean. In this sense, Turkey's engagement in the region is not only based on satisfying its energy demand, but also on exercising its own sovereign rights and advocating for those of the Turkish Cypriots. In response to Turkey, the other involved and interested parties have put forward counter-arguments and engaged in counter-maneuvers. In this conflict-ridden zone, where the disputes regarding Cyprus are key issues, the EU inherently supports the GCA, which is a member of the Union, and has threatened Turkey with severe sanctions, claiming that Turkey is violating international law through its exploration and drilling activities in the region.

A recent critical development which can shape the political situation in the region is the recent change of government in Greece. The newly-elected Greek Prime Minister Kyriakos Mitsotakis announced that both Turkey and Greece will try to build trust to avoid possible tensions in the Aegean Sea and Eastern Mediterranean within the framework of international laws, ${ }^{61}$ while Foreign Minister Nikos Dendias implied that there would be no change of attitude towards the disputes in the Eastern Mediterranean. ${ }^{62}$ As a response, President Erdoğan reiterated his decisive stance regarding Turkey's sovereignty rights in the region. ${ }^{63}$

The optimal scenario in the Eastern Mediterranean requires a positive-sum game in which the rights of all parties are thoroughly satisfied, rather than a zero-sum game. To achieve such an outcome, Turkey must be incorporated fairly in the matrix. If any step is taken toward a zero-sum game, the regional disputes could escalate further and irrevocable tensions could engulf the involved and interested parties. At this stage, three main strategic options are available to achieve a positive-sum game that would equally serve all of the parties' interests and desires in the region. The first necessitates inviting Turkey to the Eastern Mediterranean Gas Forum to increase the potential level of synergy and cooperation. The second strategic option involves the United Nations taking a role in the dispute through organizing inter-governmental discussions and providing a special representative to act as a facilitator. Third, it is important that the legal rights of the Turkish Cypriots should be considered in communications between the two communities inhabiting the island, and the guarantor states should also be willing to acknowledge and respect 
their rights both on the island and in the Eastern Mediterranean. The present moment offers a major opportunity for the interested parties, such as the U.S., Russia, and the EU, to overturn their biased and unfair policies and strategic decisions, allowing for the creation of a more constructive atmosphere.

The dynamics of the regional game in the Eastern Mediterranean are shifting as the strategic cards are being reshuffled. An equal allocation of the natural resources and the protecting all parties' sovereign rights without discrimination will facilitate the diplomatic resolution of the outstanding regional disputes. Otherwise, the involved and interested parties in the Eastern Mediterranean will likely find themselves in increasingly severe disputes regarding the future of the region.

\section{Endnotes}

1. Mehmet Efe Biresselioğlu, Cansu Yıldırım, Muhittin Hakan Demir, and Sinem Tokcaer, "Establishing an Energy Security Framework for a Fast-growing Economy: Industry Perspectives from Turkey," Energy Research \& Social Science, Vol. 27, (May 2017), pp. 151-162.

2. Mehmet Efe Biresselioğlu and Işık Özge Yumurtaci, "Evaluating the Nature of Terrorist Attacks on the Energy Infrastructure: The Periodical Study for 1970-2011," International Journal of Oil Gas and Coal Technology, Vol. 10, No. 3 (January 2015), pp. 325-341.

3. "Annual Energy Outlook 2019 with Projections to 2050," U.S. Energy Information Administration (EIA), (January 24, 2019), retrieved July 3, 2019, from https://www.eia.gov/outlooks/aeo/pdf/aeo2019.pdf.

4. Mehmet Efe Biresselioğlu, European Energy Security: Turkey's Future Role and Impact, (Basingstoke: Palgrave Macmillan, 2011).

5. Biresselioğlu, European Energy Security: Turkey's Future Role and Impact.

6. In 2019, record June temperatures were recorded in Europe and Alaska: Jeanna Bryner, "Whoa! Alaska İs Hotter than NYC. Here's Why," Live Science, (July 5, 2019), retrieved July 9, 2019, from https://www. livescience.com/65877-anchorage-alaska-record-breaking-heat.html.

7. "BP Statistical Review of World Energy," British Petroleum (BP), 68 $8^{\text {th }}$ Edition, (2019), retrieved from https://www.bp.com/content/dam/bp/business-sites/en/global/corporate/pdfs/energy-economics/ statistical-review/bp-stats-review-2019-full-report.pdf.

8. "United Nations: Kyoto Protocol to the United Nations Framework Convention on Climate Change," United Nations, (1998), retrieved from https://unfccc.int/resource/docs/convkp/kpeng.pdf; "The Paris Agreement," United Nations Climate Change, (2015), retrieved from https://unfccc.int/process-andmeetings/the-paris-agreement/the-paris-agreement.

9. International Energy Agency (IEA), "What İs Energy Security?" (2019), retrieved from https://www.iea. org/topics/energysecurity/whatisenergysecurity/.

10. "The Green Paper Presented by the European Commission towards a European Strategy for the Security of Energy Supply," Commission of the European Communities, Brussels, Belgium, (June 21, 2001), retrieved from http://aei.pitt.edu/1184/1/enegy_supply_security_gp_COM_2000_769.pdf.

11. Mehmet Efe Biresselioğlu, Tezer Yelkenci, and İbrahim Onur Oz, "Investigating the Natural Gas Supply Security: A New Perspective," Energy, Vol. 80, (February 2015), pp. 168-176.

12. "Statistical Review of World Energy Resources 68 ${ }^{\text {th }}$ (ed.)," BP, (2019), retrieved from https://www. bp.com/content/dam/bp/business-sites/en/global/corporate/pdfs/energy-economics/statistical-review/bp-stats-review-2019-full-report.pdf.

13. "Statistical Review of World Energy Resources $68^{\text {th }}$ (ed.)," $B P$. 
14. "Statistical Review of World Energy Resources $68^{\text {th }}$ (ed.)," $B P$.

15. Mehmet Efe Biresselioğlu (ed.), Enerji Güvenliği Perspektifinden Türkiye'ye Bakış [Looking at Turkey from the Perspective of Energy Security], (Enerji Hukuku Araştırma Enstitüsü [Energy Law Research Institute], (January 2015).

16. Biresselioğlu, European Energy Security: Turkey's Future Role and Impact.

17. Kostis Geropoulos, "East Med Gas Forum Wants Worldwide Upgrade," (July 31, 2019), retrieved October 22, 2019 from https://www.neweurope.eu/article/east-med-gas-forum-wants-worldwide-upgrade/.

18. Ofir Winter and Gallia Lindenstrauss, "Beyond Energy: The Significance of the Eastern Mediterranean Gas Forum," INSS Insight, No. 133 (February 3, 2019), retrieved from https://www.inss.org.il/publication/ beyond-energy-significance-eastern-mediterranean-gas-forum/.

19. "The Eastern Mediterranean's New Great Game over Natural Gas" Stratfor, (February 22, 2018,) retrieved October 21, 2019 from https://worldview.stratfor.com/article/eastern-mediterraneans-newgreat-game-over-natural-gas.

20. David Dessler, "What's at Stake in the Agent-Structure Debate?" International Organization Vol. 43, No. 3 (Summer, 1989), pp. 441-473.

21. David Dessler, “What's at Stake in the Agent-Structure Debate?” pp. 441-473.

22. "Eastern Mediterranean Region: Overview of Oil and Natural Gas in the Eastern Mediterranean Region," EIA, (August 15 2013), retrieved July 6, 2019, from https://www.eia.gov/beta/international/analysis_includes/regions_of_interest/Eastern_Mediterranean/eastern-mediterranean.pdf.

23. Isabella Ruble, "European Union Energy Supply Security: The Benefits of Natural Gas Imports from the Eastern Mediterranean," Energy Policy, Vol. 105, (June 2017), pp. 341-353.

24. Hayriye Kahveci Özgür, "Eastern Mediterranean Hydrocarbons: Regional Potential, Challenges Ahead, and the 'Hydrocarbon-ization' of the Cyprus Problem," Perceptions, Vol. 22, No. 2 (April 2019), pp. 31-56.

25. Ioannis N. Grigoriadis, "Energy Discoveries in the Eastern Mediterranean: Conflict or Cooperation," Middle East Policy, Vol. 21, No. 3, (September 2014), pp. 124-133.

26. "Eastern Mediterranean Region," EIA.

27. Zvi Ben-Avraham, John Woodside, Emanuele Lodolo, Michael Gardosh, Mario Grasso, Angelo Camerlenghi, and Gian Battista Vai, "Eastern Mediterranean Basin Systems," Geological Society, Vol. 30, (January 2006), pp. 263-276.

28. "Eastern Mediterranean Region," EIA.

29. Haluk Direskeneli, "Eastern Mediterranean Offshore Waters Are Warming - OpEd," Eurasiareview, (March 6, 2018), retrieved July 8, 2019, from https://www.eurasiareview.com/06032018-easternmediterranean-offshore-waters-are-warming-oped/.

30. Brenda Shaffer, "Eastern Mediterranean Energy: A Decade After the Major Discoveries," Turkish Policy Quarterly, (November 27, 2018), retrieved July 2, 2019, from http://turkishpolicy.com/article/936/ eastern-mediterranean-energy-a-decade-after-the-major-discoveries.

31. "Drilling Offshore Cyprus," SSGDrilling, retrieved July 7, 2019 from https://ssgdrilling.com/drilling activity_cyprus/.

32. "Statistical Review of World Energy Resources," BP.

33. Brenda Shaffer, "Eastern Mediterranean Energy: A Decade After The Major Discoveries."

34. China Internet Information Center, "Roundup: Egypt Announces New Gas Discovery in Nile Delta Area," retrieved September 30, 2019 from http://www.china.org.cn/world/Off_the_Wire/2019-7/24/ content_75024585.htm.

35. Ioannis N. Grigoriadis, "Energy Discoveries in the Eastern Mediterranean: Conflict or Cooperation."

36. Jacopo Franceschini, "Eastern Mediterranean, Turkey Boycotting Natural Resources Exploitation," Mediterranean Affairs, (July 11, 2018), retrieved July 1, 2019, from http://mediterraneanaffairs.com/ eastern-mediterranean-turkey-boycotting/. 
37. Biresselioğlu, Yelkenci and Oz, "Investigating the Natural Gas Supply Security: A New Perspective."

38. "Declarations and Statements," United Nations' Oceans and Law of the Sea, (October 19, 2019), retrieved from https://www.un.org/depts/los/convention_agreements/convention_declarations.htm.

39. Çağatay Erciyes, "Turkey's Off-Shore Activities in the Eastern Mediterranean," retrieved October 25, 2019 from http://www.mfa.gov.tr/site_media/html/maritime-delimitation-27-5-2019-presentation. pdf.

40. Ali Murat Alhas and Vakkas Doğantekin, "Turkish FM Writes to EU, UNSC Members on E. Med. Drills," Anadolu Agency, (May 17, 2019), retrieved July 7, 2019, from https://www.aa.com.tr/en/europe/turkishfm-writes-to-eu-unsc-members-on-e-med-drills/1481003.

41. "Turkey's Second Drilling Ship to Operate off Karpas Peninsula," CyprusMail, (June 20, 2019), retrieved July 6, 2019, from https://cyprus-mail.com/2019/06/20/turkeys-second-drilling-ship-to-operate-off-karpas-peninsula/.

42. Morgan Ortagus, "Turkish Drilling in Cypriot Claimed Waters," [Press Statement], U.S. Department of State, (July 9, 2019), retrieved July 10, 2019, from https://www.state.gov/turkish-drilling-in-cypriot-claimed-waters-2/.

43. Helena Smith, "Greece and Cyprus Call on EU to Punish Turkey in Drilling Dispute," The Guardian, (June 18, 2019), retrieved July 9, 2019, from https:/www.theguardian.com/world/2019/jun/18/greeceand-cyprus-call-on-eu-to-punish-turkey-in-drilling-dispute.

44. Metin Gürcan, "Eastern Mediterranean Heats Up as Gas Rivalry Stakes Grow Higher," Al-Monitor, (June 25, 2019), retrieved July 3, 2019, from https://www.al-monitor.com/pulse/originals/2019/06/turkey-eastern-mediterranean-heats-up-gas-rivalry-grows.html.

45. Nurettin Kurt, "Rising Tides of Tension in the Eastern Mediterranean," Uwidata, (May 23, 2019), retrieved July 7, 2019, from https://uwidata.com/3477-rising-tides-of-tension-in-the-eastern-mediterranean/.

46. “Erdoğan: MB Başkanı'nın Tasarrufları Neticesinde Ağır Bedeller Ödendi [Erdoğan: The Head of the Central Bank Paid the Price for the Consequences of His Austerity Measures]," Bloomberg HT, (June 10, 2019), retrieved July 10, 2019, from https://www.bloomberght.com/erdogan-mb-baskani-nin-tasarruflari-neticesinde-agir-bedeller-odendi-2228154.

47. "Turkey to Launch Second Cyprus Drill Ship on Thursday - Anadolu Reports," Euronews, (June 18, 2019), retrieved June 10, 2019, from https://www.euronews.com/2019/06/18/turkey-to-launch-secondcyprus-drill-ship-on-thursday-anadolu.

48. "Turkey's Second Drillship Yavuz to Operate in East of Cyprus by July," Daily Sabah, (June 20, 2019), retrieved July 7, 2019, from https://www.dailysabah.com/energy/2019/06/20/turkeys-second-drillshipyavuz-to-operate-in-east-of-cyprus-by-july.

49. Murat Demirci, “Kıbrıs Türk Tarafı Doğalgaz Alanındaki Haklarını Savunmaya Devam Edecek [Turkish Republic of Northern Cyprus Will Keep on Protecting Its Rights in Natural Gas Field]," Anadolu Agency, (January 25, 2019), retrieved July 8, 2019, from https://www.aa.com.tr/tr/dunya/kibris-turk-tarafi-dogalgaz-alanindaki-haklarini-savunmaya-devam-edecek/1375039\#.

50. Kahveci Özgür, “Eastern Mediterranean Hydrocarbons: Regional Potential, Challenges Ahead, and the 'Hydrocarbon-ization' of the Cyprus Problem."

51. "Tension between Turkey and Cyprus over Gas Search," Euronews, (February 11, 2018), retrieved July 5, 2019, from https://www.euronews.com/2018/02/11/tension-between-turkey-and-cyprus-over-gassearch.

52. Michele Kambas, "Standoff in High Seas as Cyprus Says Turkey Blocks Gas Drill Ship," Reuters, (February 11,2018$)$, retrieved July 8,2019 , from https://www.reuters.com/article/us-cyprus-natgas-turkeyship/standoff-in-high-seas-as-cyprus-says-turkey-blocks-gas-drill-ship-idUSKBN1FV0X5.

53. “Cumhurbaşkanlığı Sözcüsü İbrahim Kalın'dan Önemli Açıklamalar [Significant Remarks from Presidential Spokesperson Ibrahim Kalın]," Hürriyet, (June 13, 2019), retrieved July 5, 2019, from http://www. hurriyet.com.tr/gundem/cumhurbaskanligi-sozcusu-ibrahim-kalindan-onemli-aciklamalar-41243406.

54. Franceschini, “Eastern Mediterranean, Turkey Boycotting Natural Resources Exploitation.” 
55. Ömer Bilge, "Türkiye'yi Bypass Eden Haritaya Çok Sert Tepki! [Strong Reaction to the Map Bypassing Turkey!]," Hürriyet, (May 9, 2018), retrieved July 1, 2019, from http://www.hurriyet.com.tr/dunya/turkiyeyi-bypass-eden-haritaya-cok-sert-tepki-40830701.

56. Athanasios Athanasiou, "Anastasiades Informs Tusk on EEZ and Varosha Anastasiades Informs," Brief, (June 20, 2019), retrieved July 2, 2019 from https://www.brief.com.cy/english/anastasiades-informstusk-eez-and-varosha-developments.

57. Caroline Mortimer, "Turkey-Cyprus Dispute: Why Are the Two Countries Arguing over Drilling Rights?" Euronews, (June 25, 2019), retrieved July 4, 2019, from https://www.euronews.com/2019/06/ 24/turkey-cyprus-dispute-why-are-the-two-countries-arguing-over-drilling-rights.

58. Murad Sezer, "Turkey Sends Second Ship to Drill Near Cyprus, EU Warns of Action," Reuters, (June 20, 2019), retrieved July 7, 2019, from https://af.reuters.com/article/worldNews/idAFKCN1TL1BO.

59. "Turkey Deems US Statement 'Unrealistic,' Cyprus Vows 'International Arrest Warrant,"' Bianet, (May 6, 2019), retrieved July 5, 2019, from https://bianet.org/english/world/208191-turkey-deems-us-statement-unrealistic-cyprus-vows-international-arrest-warrant.

60. Kadri Taştan and Tobias Kutschka, "The Implications of Eastern Mediterranean Gas for Turkey," The German Marshall Fund of the United States, No. 7, (April 15, 2019), retrieved July 5, 2019, from https:// www.sigmaturkey.com/the-implications-of-eastern-mediterranean-gas-for-turkey-energy/.

61. Stelyo Berberakis, "Kiryakos Miçotakis Kimdir? Yunanistan'ın Ülke Siyasetine Damga Vuran Bir Aileden Gelen Yeni Başbakanı [Who İs Kyriakos Mitsotakis? New Prime Minister Coming From a Family That Has an Impact on Greek Politics]," BBC News, (July 8, 2019), retrieved July 11, 2019, from https://www.bbc. com/turkce/haberler-dunya-48907540.

62. "Turkey's Yavuz to Begin Drilling Off Eastern Cyprus," Daily Sabah, (July 10, 2019), retrieved July 11, 2019 from https://www.dailysabah.com/diplomacy/2019/07/10/turkeys-yavuz-drilling-ship-arrives-offeastern-cyprus.

63. "Turkey 'Hopes' for a New Era with Greece under New Mitsotakis Government," Hürriyet Daily News, (July 8, 2019), retrieved July 10, 2019, from http://www.hurriyetdailynews.com/greek-elections-opposition-nd-wins-landslide-victory-144781. 